\title{
Pengalaman Transplantasi Ginjal pada Anak di Jakarta
}

\author{
Sudung O. Pardede, Eka Laksmi Hidayati, Cahyani Gita Ambarsari, Henny Adriani Puspitasari, Partini P. Trihono, Taralan \\ Tambunan \\ Departemen Ilmu Kesehatan Anak Fakultas Kedokteran Universitas Indonesia Rumah Sakit Cipto Mangunkusumo, Jakarta
}

Latar belakang. Transplantasi ginjal merupakan terapi yang efektif untuk penyakit ginjal kronik (PGK) stadium 5 atau gagal ginjal terminal. Transplantasi ginjal di dunia pertama kali dilakukan pada tahun 1950an. Di Indonesia, transplantasi ginjal pada orang dewasa telah dilakukan pada tahun 1977 dan semakin berkembang dan telah dilakukan di beberapa kota di Indonesia. Transplantasi ginjal pada anak pertama kali dilakukan di Rumah Sakit Dr. Cipto Mangunkusomo pada bulan Maret 2013, terhadap seorang anak lelaki berusia 13 tahun dengan gagal ginjal terminal yang disebabkan sindrom nefrotik, dengan ginjal yang diperoleh dari non-related living donor. Ini merupakan transplantasi ginjal yang pertama kali dilakukan pada anak di Indonesia.

Tujuan. Melaporkan data tentang kegiatan transplantasi ginjal yang dilakukan di Jakarta.

Metode. Penelitian ini merupakan penelitian retrospektif yang mengambil data dari catatan medis. Hingga tahun 2018 telah dilakukan 11 kali transplantasi ginjal pada 10 orang anak terdiri atas 9 laki-laki dan 1 perempuan, dengan 1 kasus re-transplan. Rentang usia adalah 8-18 tahun, dengan penyakit dasar terdiri atas sindrom nefrotik (3 anak), dan ginjal hipoplasia (7 anak). Donor untuk kesebelas transplan anak tersebut terdiri atas 4 non-related living donor dan 7 orang related living donor, yaitu 5 orang donor ayah dan 2 orang donor ibu.

Hasil. Di antara 10 pasien transplan, 3 orang menggunakan biaya pribadi atau asuransi swasta dan 8 orang dengan biaya dari Badan Penyelenggara Jaminan Sosial (BPJS). Hingga bulan Agustus 2018, di antara kesepuluh anak tersebut, 7 orang hidup dan di antaranya 2 orang mengalami rejeksi pada tahun ke-3 (1 orang konversi kembali ke hemodialisis dan 1 orang telah menjalani re-transplan). Tiga pasien meninggal akibat infeksi berat.

Kesimpulan. Transplantasi ginjal di Rumah Sakit Dr. Cipto Mangunkusomo dimulai pada tahun 2013, dengan donor hidup yang sebagian besar berasal dari orangtua, dengan pembiayaan sebagian besar menggunakan BPJS. Sari Pediatri 2019;21(1):44-9

Kata kunci: anak, penyakit ginjal kronik, transplantasi ginjal

\section{Experiences of Paediatric Kidney Transplantation in Jakarta}

Sudung O. Pardede, Eka Laksmi Hidayati, Cahyani Gita Ambarsari, Henny Adriani Puspitasari, Partini P. Trihono, Taralan Tambunan

Background. Kidney transplantation is considered an effective treatment for stage 5 chronic kidney disease (CKD) or end-stage renal disease. The world's first successful kidney transplant was done in 1950s. In Indonesia, kidney transplant procedure in adult was done in 1977 and has been performed in several hospitals ever since. The first kidney transplantion in children was done in Cipto Mangukusumo Hospital in March 2013 on a 13-year-old boy suffering from end stage renal disease due to nephrotic syndrome, with a non-related living donor. This marked the first kidney transplant procedure ever performed in children in Indonesia.

Objective. To report data on kidney transplant activities carried out in Jakarta

Methods. This was a retrospective study collecting data from medical records. Until 2018, there have been 11 kidney transplant procedures performed in 10 children consisted of 9 boys and 1 girl, with 1 re-transplant case. The age of the children was between 8 - 18 years old with underlying diseases consisted of nephrotic syndrome ( 3 children), and kidney hypoplasia ( 7 children). Donors were 4 non-related living donors and 7 related living donors consisted of 5 fathers and 2 mothers.

Result. Among 10 kidney transplant patients, 3 children were privately funded and 8 children were funded by the Social Insurance Administration Organization/Badan Penyelenggara Jaminan Sosial (BPJS). By August 2018, among those 10 children, 7 children were still alive with 2 children suffered from rejection in the third year (one converted back to hemodialysis and another underwent re-transplant). Three children died from infection.

Conclusion. Kidney transplantation program in Cipto Mangunkusumo Hospital Jakarta has been started since 2013, with most of the living donors were parents and most of them were funded by BPJS. Sari Pediatri 2019;21(1):44-9

Keywords: children, chronic kidney diseases, kidney transplantation

Alamat korespondensi: Sudung O. Pardede. Departemen Ilmu Kesehatan Anak Rumah Sakit Cipto Mangunkusumo - Fakultas Kedokteran Universitas Indonesia, Jakarta. Email: suopard@yahoo.com 


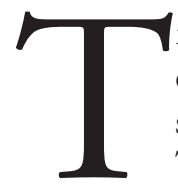

ransplantasi ginjal merupakan terapi yang efektif untuk penyakit ginjal kronik (PGK) stadium 5 atau gagal ginjal terminal. Transplantasi ginjal di dunia pertama kali dilakukan pada tahun 1950-an. Dalam enam dekade terakhir, para ahli yang terlibat dalam transplantasi ginjal anak mengembangkan pengetahuan dan pemahaman yang lebih baik mengenai respons sistem imun melalui berbagai penelitian multisenter. Perkembangan ini membuat perubahan dalam pemilihan dan tata laksana jangka panjang dengan imunosupresan, sehingga menghasilkan kesintasan pasien dan graft yang lebih baik. Pada tahun 1960-an, dilakukan transplantasi ginjal pada anak dan membuat transplantasi ginjal pada anak semakin berkembang. ${ }^{1,2,3}$

Di Indonesia, transplantasi ginjal pada orang dewasa telah dilakukan pada tahun 1977 dan semakin berkembang sehingga transplantasi ginjal telah dilakukan di beberapa rumah sakit di Indonesia. Divisi Nefrologi Departemen Ilmu Kesehatan Anak FKUI-RSCM memiliki Pusat Ginjal Anak yang dapat melakukan berbagai modalitas dalam bidang nefrologi anak, baik untuk tindakan diagnostik maupun terapeutik, seperti pemeriksaan laboratorium, pemeriksaan pencitraan, tindakan biopsi ginjal, pelayanan hemodialisis, dialisis peritoneal, maupun continuous renal replacement therapy (CRRT). Hemodialisis anak mulai dilakukan di unit khusus anak pada bulan September 2012, dimulai dengan satu mesin hemodialisis dan sejak tahun 2017 dengan 5 mesin hemodialisis. Dialisis peritoneal pada anak dalam bentuk dialisis peritoneal mandiri berkesinambungan (continuous ambulatory peritoneal dialysis, CAPD) telah dimulai pada tahun 2014 dan saat ini ada 33 pasien anak dengan CAPD yang dilayani di Pusat Ginjal Anak RSCM. Pelayanan dialisis anak ini merupakan bagian dari pengembangan untuk melakukan transplantasi ginjal.

Transplantasi ginjal pada anak pertama kali dilakukan di Rumah Sakir Dr. Cipto Mangunkusumo Jakarta pada bulan Maret 2013, terhadap seorang anak lelaki berusia 13 tahun, pasien gagal ginjal terminal yang disebabkan sindrom nefrotik, dengan ginjal yang diperoleh dari non-related living donor. Transplantasi ini merupakan transplantasi ginjal yang pertama dilakukan pada anak di Indonesia, dan memberikan hasil yang baik, tidak terdapat reaksi rejeksi maupun komplikasi.

Penelitian ini bertujuan melaporkan data tentang kegiatan transplantasi ginjal yang dilakukan di Jakarta.

\section{Metode}

Penelitian ini merupakan penelitian retrospektif berupa laporan seri kasus pasien anak yang menjalani transplantasi ginjal di RS Cipto Mangunkusumo, Jakarta. Data diperoleh dari rekam medis meliputi umur, jenis kelamin, penyakit dasar, sumber donor, pembiayaan, persiapan pretranplantasi, pascatransplantasi, dan keadaan akhir pasien. Dicatat data atau keterangan tentang persiapan baik pada donor maupun pada resipien, dan disajikan dalam bentuk tekstular dan tabular.

\section{Hasil}

Di Rumah Sakit Dr. Cipto Mangunkusomo sejak bulan Maret 2013 hingga Agustus 2018, telah dilakukan 11 kali transplantasi ginjal terhadap 10 orang anak terdiri atas 9 laki-laki dan 1 perempuan, dengan 1 kasus retransplantasi. Rentang usia adalah 8-18 tahun, dengan penyakit dasar terdiri atas sindrom nefrotik (3 anak) dan hipoplasia ginjal (7 anak). Donor untuk kesebelas transplan anak tersebut terdiri atas 4 non-related living donor dan 7 orang related living donor, yaitu 5 orang donor ayah dan 2 orang donor ibu.

Transplantasi ginjal pada anak merupakan kegiatan tim yang terdiri atas nefrologi, bedah urologi, anestesiologi, infeksi dan penyakit tropik, kardiologi, pulmonologi, gastroenterologi, psikiatri, telinga-hidung-tenggorokan, dietisien/gizi klinik, dan bidang lain sesuai kebutuhan kondisi klinis pasien. Pada persiapan transplantasi ginjal dilakukan pemeriksaan fisik dan pemeriksaan laboratorium meliputi pemeriksaan darah tepi lengkap, uji fungsi hati, fungsi ginjal, fungsi tiroid, elektrolit $(\mathrm{Na}, \mathrm{K}$, $\mathrm{Cl}, \mathrm{Ca}$, bikarbonat, fosfat), profil besi, pemeriksaan serologis (HIV, $\mathrm{HBsAg}$, anti-HBs, anti-HBc, anti $\mathrm{HCV}$, virus Ebstein-Barr (EBV), virus CMV, TORCH), urinalisis, serta kultur urin dan darah. Dilakukan juga pemeriksaan PCR terhadap CMV, EBV, toksoplasma, rubella, HSV I dan II), evaluasi kardiologi termasuk foto Rontgen dada dan ekokardiografi, serta evaluasi uroradiologik seperti computed tomographic (CT) angiogram, DMSA renal scan, atau renal angiogram atas indikasi. Pemeriksaan tissue typing meliputi pemeriksaan darah $\mathrm{ABO}, \mathrm{Rh}$, human leukocyte antigen (HLA) class I,II, recipient-donor $T$ and B-cell direct crossmatch. Evaluasi sistem urologi dilakukan dengan 
pemeriksaan ultrasound, micturating cystourethrogram, urodinamik. Status imunisasi dilengkapi untuk difteri-pertusis-tetanus, polio, hepatitis $\mathrm{B}$, hemofilus influenza tipe $\mathrm{B}$, campak, mumps, rubela, varisela, pneumokokus, dan HPV.

Pada donor hidup dilakukan evaluasi persiapan transplantasi meliputi pemeriksaan darah tepi, ureum, kratinin, asam urat, elektrolit $(\mathrm{Na}, \mathrm{K}, \mathrm{Cl}, \mathrm{Ca}$, bikarbonat, fosfat), uji fungsi hati, lemak (trigliserida, kolesterol total, kolesterol HDL, kolesterol LDL), gula darah, kadar tiroksin, serologis HIV, pemeriksaan serologis terhadap hepatitis B (HBsAg, anti-HBs, anti$\mathrm{HBc}$ ), hepatitis $\mathrm{C}$, virus Ebstein-Barr, virus CMV, dan sifilis, serta pemeriksaan urinalisis dan biakan urin. Dilakukan evaluasi kardiologi termasuk foto Rontgen dada dan ekokardiografi, serta evaluasi uroradiologik seperti USG ginjal dan saluran kemih, computed tomographic (CT) angiogram. Pemeriksaan tissue typing meliputi pemeriksaan darah $\mathrm{ABO}, \mathrm{Rh}$, human leukocyte antigen (HLA) class I,II, recipient-donor $T$ and B-cell direct crossmatch.

Dilakukan evaluasi psikososial dan psikiatri. Aspek etik dan legal ditangani oleh satu tim khusus, dan tidak boleh ada hal yang menyangkut jual beli organ.

Operasi pengambilan ginjal dari donor dan penempatan ginjal ke resipien dilakukan oleh dokter bedah urologi. Setelah tindakan operasi, dilakukan pemantauan dimulai dari ruang pemulihan hingga pasien dirawat di ruang perawatan khusus transplantasi atau ruang pediatric intensive care unit sesuai dengan kondisi pasien. Selama perawatan pascaoperasi, dilakukan pemantauan hemodinamik dan respirasi, produksi urin setiap jam, pemeriksaan laboratorium sesuai indikasi, dan komplikasi.

Obat imunosupresan yang digunakan sebelum operasi adalah metilprednisolon, takrolimus, dan

Tabel 1. Profil pasien anak yang menjalani transplantasi ginjal di RSCM

\begin{tabular}{|c|c|c|c|c|c|c|c|c|}
\hline No & $\begin{array}{l}\text { Umur } \\
\text { (tahun) }\end{array}$ & Sex & $\begin{array}{l}\text { Waktu } \\
\text { transplantasi }\end{array}$ & Penyakit dasar & $\begin{array}{c}\text { Sumber } \\
\text { donor }\end{array}$ & Pembiayaan & $\begin{array}{c}\text { Keadaan akhir } \\
(2018)\end{array}$ & Keadaan graft \\
\hline 1 & 11 & $\mathrm{~L}$ & Maret 2013 & Sindrom nefrotik & $\begin{array}{l}\text { Non } \\
\text { related }\end{array}$ & Pribadi & $\begin{array}{l}\text { Hidup, transfer ke } \\
\text { dewasa }\end{array}$ & $\begin{array}{l}\text { Fungsi ginjal } \\
\text { normal }\end{array}$ \\
\hline 2 & 14 & $\mathrm{~L}$ & 2013 & Sindrom nefrotik & Ibu & BPJS + Pemda & $\begin{array}{c}\text { Hidup, transfer ke } \\
\text { dewasa }\end{array}$ & $\begin{array}{c}\text { Graft failure, } \\
\text { non adherence, } \\
\text { hemodialisis }\end{array}$ \\
\hline 3 & 10 & $\mathrm{~L}$ & 2014 & Ginjal hipoplasia & Ayah & BPJS & $\begin{array}{l}\text { Meninggal,< } \\
1 \text { tahun pasca } \\
\text { transplantasi }\end{array}$ & $\begin{array}{c}\text { Aktivasi infeksi } \\
\text { CMV }\end{array}$ \\
\hline 4 & 8 & $\mathrm{~L}$ & 2015 & Ginjal hipoplasia & Ayah & BPJS & $\begin{array}{l}\text { Meninggal,< } \\
1 \text { tahun pasca } \\
\text { transplantasi }\end{array}$ & Pneumonia \\
\hline 5 & 15 & $\mathrm{~L}$ & 2015 & Ginjal hipoplasia & $\begin{array}{l}\text { Non } \\
\text { related }\end{array}$ & BPJS & Hidup & $\begin{array}{c}\text { Graft failure, rejeksi } \\
\text { kronik }\end{array}$ \\
\hline 6 & 18 & $\mathrm{~L}$ & 2015 & $\begin{array}{l}\text { Ginjal hipoplasia, } \\
\text { single kidney }\end{array}$ & Ibu & BPJS & $\begin{array}{l}\text { Meninggal, < } \\
1 \text { tahun pasca } \\
\text { transplantasi }\end{array}$ & Pneumonia \\
\hline 7 & 15 & $\mathrm{~L}$ & 2016 & Ginjal hipoplasia & Ayah & BPJS & Hidup & $\begin{array}{l}\text { Fungsi ginjal } \\
\text { normal }\end{array}$ \\
\hline 8 & 13 & $\mathrm{~L}$ & 2017 & Ginjal hipoplasia & Ayah & BPJS & Hidup & $\begin{array}{l}\text { Fungsi ginjal } \\
\text { normal }\end{array}$ \\
\hline 9 & 11 & $\mathrm{P}$ & 2017 & Sindrom nefrotik & $\begin{array}{l}\text { Non } \\
\text { related }\end{array}$ & Pribadi & Hidup & $\begin{array}{l}\text { Fungsi ginjal } \\
\text { normal }\end{array}$ \\
\hline 10 & 8 & $\mathrm{~L}$ & 2018 & Ginjal hipoplasia & Ayah & BPJS & Hidup & $\begin{array}{l}\text { Fungsi ginjal } \\
\text { normal }\end{array}$ \\
\hline 11 & 17 & $\mathrm{~L}$ & 2018 & Retransplant & $\begin{array}{l}\text { Non } \\
\text { related }\end{array}$ & BPJS & $\begin{array}{c}\text { Hidup, transfer ke } \\
\text { dewasa }\end{array}$ & $\begin{array}{c}\text { Retransplant (kasus } \\
\text { nomor } 5 \text { ) }\end{array}$ \\
\hline
\end{tabular}


basiliximab dan setelah operasi diberikan satu kali basiliximab, kemudian metilprednisolon, takrolimus, mikofenolat mofetil,

Di antara pasien transplan tersebut, 2 orang menggunakan pembiayaan pribadi atau asuransi swasta dan 9 orang dengan biaya dari Badan Penyelenggara Jaminan Sosial (BPJS). Hingga bulan Agustus 2018, di antara kesepuluh anak tersebut, saat ini 7 orang hidup, di antaranya 2 orang mengalami rejeksi pada tahun ke-3 ( 1 orang konversi kembali ke hemodialisis dan 1 orang telah menjalani re-transplan). Tiga orang pasien meninggal karena infeksi berat dan pneumonia.

\section{Pembahasan}

Transplantasi ginjal merupakan terapi yang efektif untuk penyakit ginjal kronik (PGK) stadium 5 atau gagal ginjal terminal. ${ }^{2,3,4}$ Transplantasi ginjal pada anak di dunia pertama kali dilakukan pada tahun 1960an. ${ }^{1}$ Beberapa negara Asia telah lebih dahulu melakukan transplantasi ginjal pada anak. Di Korea Selatan, transplantasi ginjal pertama kali dilakukan pada tahun 1979. Di Sri Lanka, transplantasi ginjal anak telah dilakukan di Teaching Hospital Peradeniya dan sejak tahun 2004 telah dilakukan transplantasi ginjal pada 69 dengan donor hidup. Di Thailand, transplantasi ginjal pada anak pertama kali dilakukan pada tahun $1996 .{ }^{5}$ Di Oman, transplantasi ginjal dimulai tahun 1988. Pada tahun 1993, Oman menerbitkan undang-undang tentang transplantasi yang hanya membolehkan transplantasi dengan donor living related, melarang komersialisasi transplantasi, dan membolehkan donor diperoleh dari jenazah. ${ }^{6}$ Di Brazil pada tahun 1998 hingga 2010 telah dilakukan transplantasi ginjal pada 62 anak berusia $<15$ tahun, ${ }^{7}$ di Afrika transplantasi ginjal pada anak dilakukan pada tahun 1968 di rumah sakit di Cape Town, Afrika Selatan. ${ }^{8}$

Di Jakarta, transplantasi ginjal pada anak pertama kali dilakukan di Rumah Sakir Dr. Cipto Mangunkusomo pada bulan Maret 2013. dan memberikan hasil yang baik, tidak terdapat reaksi rejeksi maupun komplikasi. Keterlambatan negara Indonesia melaksanakan transplantasi ginjal pada anak disebabkan beberapa faktor antara lain masalah sumber daya manusia, sarana rumah sakit, pembiayaan, kesulitan mendapatkan donor, maupun faktor budaya.

Transplantasi ginjal memerlukan persiapan yang baik. Secara umum, persiapan transplantasi ginjal pada anak hampir sama dengan dewasa, meliputi pemeriksaan laboratorium, pemeriksaan pencitraan, maupun pemeriksaan penunjang yang berkaitan dengan fungsi dan anatomi ginjal dan saluran kemih, serta konsultasi dengan berbagai bidang keilmuan. ${ }^{2-4,9}$ Pada penelitian ini, telah dilakukan persiapan baik terhadap resipien maupun donor dengan pemeriksaan fisik, pemeriksaan penunjang, dan konsultasi dengan bidang terkait. Aspek etik dan legal merupakan hal yang sangat penting dan dilakukan oleh satu tim khusus.

Pemilihan donor merupakan aspek medis praoperasi yang sangat penting pada transplantasi ginjal. Donor dapat berasal dari donor hidup (living donor) atau donor jenazah (deceased donor). Donor hidup dapat bersifat related (keluarga/keturunan), emotionally related, maupun unrelated.. Di Malaysia, donor untuk transplantasi ginjal pada anak berasal dari donor jenazah pada 57\% sedangkan living related donor pada 32\%. Di Thailand hingga tahun 2010 telah dilakukan sebanyak 201 transplantasi ginjal pada anak dengan donor sebagian besar (67\%) berasal dari donor jenazah. Graft survival rate 1 dan 5 tahun adalah $95 \%$ dan $76 \%$. Di Vietnam, di antara 900 kasus transplantasi ginjal, hanya 25 orang mendapat ginjal dari donor hidup pada anak usia 15 tahun. ${ }^{5}$ Di Iran, di antara 32 orang yang menjalani transplantasi ginjal, 5 orang donor berasal dari donor jenazah, 12 dari donor living related, dan 15 dari donor living unrelated. ${ }^{10}$ Di Oman, di antara 70 orang anak yang menjalani transplantasi ginjal, 27 $(38,5 \%)$ anak mendapat donor living related, 42 anak dengan donor living unrelated, dan 1 anak dengan donor jenazah. Donor living related terdiri atas ibu $(48,0 \%)$, ayah (19,0\%), bibi (17,0\%), paman (11\%), dan saudara kandung (7\%). ${ }^{6}$ Di Jakarta, donor untuk kesebelas transplan anak tersebut terdiri atas 4 nonrelated living donor dan 7 orang related living donor, yaitu 5 orang donor ayah dan 2 orang donor ibu. Hingga saat ini transplanatsi ginjal menggunakan donor hidup dan tidak ada yang menggunakan donor jenazah. Pada laporan ini, semua donor merupakan donor hidup karena di Indonesia, donor yang diperbolehkan adalah donor hidup, sedangkan donor jenazah belum disetujui karena menyangkut masalah budaya dan agama.

Di Korea Selatan, sejak tahun 1979 hingga 2010 telah dilakukan 498 kali transplantasi ginjal pada 488 anak berusia kurang dari 18 tahun atau 16,6 transplantasi per tahun. Di Pakistan, di Sindh 
Institute of Urology and Transplantation, Karachi telah dilakukan transplantasi ginjal pada 475 anak usia 18 tahun antara tahun 2006-2011. Di Filipina, antara tahun 1985-2013, telah dilakukan transplantasi ginjal pada 134 anak usia 19 tahun (rata-rata 4,7 per tahun), dengan donor berupa $109(81,3 \%)$ living donor dan 25 (18,7\%) donor jenazah (deceased donor). ${ }^{5}$ Di Iran bagian Selatan, selama 5 tahun (1989-1994) telah dilakukan transplantasi ginjal pada 32 (rata-rata 6 per tahun) anak dan remaja berumur 5-19 tahun yang terdiri atas 18 laki-laki dan 14 perempuan. ${ }^{10}$ Selama 22 tahun (Januari 1994 hingga Desember 2015) di Oman telah dilakukan transpplantasi ginjal pada 70 orang anak (rata-rata 3,5 anak per tahun) dengan median umur 9 tahun. ${ }^{6}$ Di Jakarta, selama 5 tahun (Maret 2013 hingga Agustus 2018), telah dilakukan 11 kali transplantasi ginjal pada 10 orang anak atau rata-rata 2 pasien setahun, terdiri atas 9 laki-laki dan 1 perempuan. Jumlah transplantasi ginjal di Indonesia lebih rendah dibandingkn negara lain karena beberapa faktor antara lain kesulitan mencari donor hidup karena di Indonesia, transplantasi ginjal baru menggunakan donor hidup sedangkann donor jenazah belum terlaksana, ketidak tahuan masyarakat, masalah biaya, dan soail budaya.

Di Iran Bagian Selatan, diagnosis pretransplantasi terdiri atas glomerulonefritis membranoproliferatif (3), glomerulonefritis kronik (4), glomerulonefritis progresif cepat (1), pielonefritis (3), nefronoptisis (1), nefropati refluks (3), uropati obstruktif (4), asidosi tubulus renalis (1), nekrosis tubular akut (1), dan 11 tidak diketahui. Pasien ini telah menjalani dialisis antara 6 bulan hingga 2 tahun. Komplikasi pasca tranplantasi adalah nekrosis tubular akut (6), rejeksi akut reversibel (5), uropati obstruktif (2), dan urinoma (1). ${ }^{10} \mathrm{Di}$ Oman, diagnosis pretransplantasi di antara 70 anak terdiri atas congenital anomalies of the kidney and urinary tract (CAKUT) 32,8\%, sindrom nefrotik familial 20,0\%, dan penyakit ginjal polikistik $18,5 \%{ }^{6}$ Di Jakarta, diagnosis pretransplantasi ginjal penyebab gagal ginjal stadium akhir adalah sindrom nefrotik (3 anak) dan hipoplasia ginjal (7 anak) dengan penyebab yang tidak jelas.

Infeksi merupakan penyebab tersering anak dengan transplantasi ginjal dirawat di rumah sakit dan penyebab kematian. ${ }^{1,11}$ Di Iran, satu di antara 32 pasien meninggal karena sepsis. ${ }^{10}$ Selama 5 tahun, di Jakarta telah dilakukan 11 kali transplantasi ginjal terhadap 10 orang. Di antara ke sepuluh orang, 3 orang meninggal dalam waktu kurang dari satu tahun, dan 7 orang hidup ( 4 bulan hingga 5 tahun 3 bulan), 5 anak dengan fungsi ginjal normal, 2 orang mengalami rejeksi pada tahun ke-3 (1 orang konversi kembali ke hemodialisis dan 1 orang telah menjalani re-transplan). Tiga orang pasien meninggal karena infeksi berat dan pneumonia.

Dalam melaksanakan transplantasi ginjal pada anak, perlu diidentifikasi masalah finansial. ${ }^{9}$ Biaya yang dibutuhkan untuk transplantasi ginjal sangat mahal, berkisar antara Rp. 350-500 juta yang umumnya tidak terjangkau oleh pasien, dan hanya dapat dilakukan oleh pasien yang mempunyai dana yang cukup atau yang dibiayai asuransi. Pemerintah Indonesia menanggung biaya transplantasi ginjal dengan pembiayaan oleh BPJS. Hal ini terlihat bahwa hanya 2 transplantasi ginjal yang dibiayai dengan biaya pribadi atau asuransi pribadi, dan 9 kali transplantasi ginjal dibiayai oleh BPJS. Namun masih ada biaya yang harus ditanggung oleh keluarga.

Transplantasi ginjal pada anak merupakan tindakan yang memerlukan persiapan yang memerlukan persiapan yang menghadapi berbagai kendala, antara lain kesulitan melakukan pemeriksaan tertentu, kesulitan memperoleh donor, masalah pembiayaan. Persiapan yang baik dan kerja sama dalam tim transplantasi merupakan kunci keberhasilan transplantasi ginjal pada anak.

\section{Kesimpulan}

Tindakan transplantasi ginjal di Departemen Ilmu Kesehatan Anak FKUI-RSCM dimulai pada tahun 2013, dengan donor hidup yang sebagian besar berasal dari orangtua, dengan pembiayaan sebagian besar menggunakan BPJS. Angka kesintasan masih berada di bawah rerata kesintasan di negara maju.

\section{Daftar pustaka}

1. Verghese PS. Pediatric kidney transplantation: a historical review. Pediatr Res 2012;1:259-64.

2. Rodiq NM, Vakili K, Harmon WE. Pediatric renal transplant. Dalam: Avner ED, Harmon WE, Niaudet P, Yoshikawa N, Emma F, Goldstein SL, penyunting, Pediatric Nephrology, edisi ketujuh, New York: Springer Reference; 2016,h.2501-52.

3. Moudgil A, Jordan SC. Renal transplantation. Dalam: Kher KK, Schnaper HW, Greenbaum LA, penyunting. 
Clinical Pediatric Nephrology, edisi ketiga, New York: CRC Press;2017.h.742-73.

4. Yap HK, Lau PYW, Ng KH, Pre-transplant evaluation of potential recipient. Dalam: Yap $\mathrm{HK}$, Liu ID, $\mathrm{Ng} \mathrm{KH}$, penyunting, Pediatric Nephrology: On The Go. Edisi ketiga, Singapore: Children's Kidney Centre; 2018.h.671-4.

5. Yap HK, Chiu MN, Bagga A, Safouh H. AsPNA. Dalam: Avner ED, Harmon WE, Niaudet P, Yoshikawa N, Emma F, Goldstein SL, penyunting, Pediatric Nephrology. Edisi ketujuh, New York: Springer Reference; 2016,h.2639-63.

6. Al Riyami MS, Al Saidi S, Al Gaithi B, Al Maskan A, Lala S, Mohsin N, dkk. Pediatric renal transplantation in Oman: A single center experience. Oman Med J 2018;1:7-14.

7. Koch V, Orta N, Exeni R. ALANEPE. Dalam: Avner ED, Harmon WE, Niaudet P, Yoshikawa N, Emma F, Goldstein SL, penyunting, Pediatric Nephrology. Edisi ketujuh, New York: Springer Reference; 2016,h.2631-8.
8. McCulloch M, Safouh H, Bourquia A, Gajjar P. AFPNA. Dalam: Avner ED, Harmon WE, Niaudet P, Yoshikawa N, Emma F, Goldstein SL, penyunting, Pediatric Nephrology. Edisi ketujuh, New York: Springer Reference; 2016.h.2613-30.

9. Yap HK, Qader MA, Liu ID, Lau PYW, Live donor evaluation. Dalam: Yap HK, Liu ID, Ng KH, penyunting, Pediatric Nephrology: On The Go. Edisi ketiga. Singapore:, Children's Kidney Centre; 2018.h.667-9.

10. Hashemi GH, Hosseini SAM, Fallah-Zadeh MH, Javid R, Ghahramani N. Kidney transplantation in children and adolescents of Southern Iran. Med J Islamic Rep Iran 1999;1:79 .

11. Dhanrnidharka VR, Araya CE. Complications of pediatric renal transplantation. Dalam: Avner ED, Harmon WE, Niaudet P, Yoshikawa N, Emma F, Goldstein SL, penyunting, Pediatric Nephrology. Edisi ketujuh, New York: Springer Reference; 2016,h.2573-603. 